\title{
Penilaian Berbasis Portofolio pada Peningkatan Aktivitas dan Hasil Belajar Mahasiswa Semester 1 Pendidikan Matematika STKIP Muhammadiyah Kuningan
}

\author{
Zuli Nuraeni ${ }^{*}$ \\ ${ }^{1}$ STKIP Muhammadiyah, Kuningan, Jawa Barat 45511, Indonesia \\ Pengiriman: 30 Oktober 2018; Diterima: 23 April 2019; Publikasi: 30 April 2019 \\ DOI: https://doi.org/10.31629/jg.v4i1.797
}

\begin{abstract}
Abstrak
Penelitian ini merupakan penelitian tindakan kelas (PTK) dengan subyek penelitian mahasiswa semester I pendidikan matematika STKIP Muhammadiyah Kuningan. Penelitian ini bertujuan untuk meningkatkan aktivitas dan hasil belajar mahasiswa pada mata kuliah Pengantar Dasar Matematika tahun akademik 2017/2018. Penelitian dilaksanakan melalui 2 siklus. Pada pre test rata-rata hasil belajar yang dicapai adalah 43, pada siklus I rata-rata hasil belajar menjadi 68,4 meningkat 25,4 atau sebesar 59\%, sedangkan pada siklus II rata-rata hasil belajar menjadi 90 meningkat 21,6 dari siklus I atau sebesar 31,58\%. Rata-rata aktivitas klasikal pada siklus I adalah72,36 sedangkan pada siklus II meningkat 12,74 menjadi 85,1, terjadi peningkatan 17,61\%. Rata-rata hasil belajar portofolio pada siklus I adalah 77,80 sedangkan pada siklus II meningkat 8,43 menjadi 86,24, terjadi peningkatan 10,84\%. Hasil penelitian menunjukkan pembelajaran dengan penilaian berbasis portofolio dapat meningkatkan aktivitas dan hasil belajar mahasiswa.
\end{abstract}

Kata kunci: penilaian portofolio; aktivitas dan hasil belajar

\begin{abstract}
This study is a classroom action research (CAR) with research subjects of the first semester students of mathematics education STKIP Muhammadiyah Kuningan. This study aims to improve the activities and learning outcomes of students in the Introduction to Mathematics Basics 2017/2018 academic year. The research was carried out through 2 cycles. In the pre-test the average score achieved was 43 , in the first cycle the average value became 68.4 increased by 25.4 or by $59 \%$, whereas in the second cycle the average value became 90 increased by 21.6 from the first cycle or amounting to $31.58 \%$. The average classical activity value in cycle I was 72.36 while in cycle II it increased 12.74 to 85.1 , an increase of $17.61 \%$. The average portfolio value in the first cycle was 77.80 while in the second cycle it increased 8.43 to 86.24 , an increase of $10.84 \%$. The results of the study show that learning with portfolio-based assessment can increase student activity and learning outcomes.
\end{abstract}

Keywords: portfolio assessment; activity and learning outcomes

\section{Pendahuluan}

Dalam pendidikan, tiga hal berikut harus dikuasai oleh seorang guru, yaitu kurikulum, proses pembelajaran, dan sistem penilaiannya

*Penulis Korespondensi

Email Address: zulinuraeni.wsb@gmail.com

Handphone : : +62 85643009134 dan ketiganya harus dikuasai secara seimbang. Untuk mengetahui keberhasilan perlu alat yang dinamakan evaluasi. Dalam evaluasi perlu dibedakan dua hal ini, yaitu pengukuran 


\section{JURNAL GANTANG. APRIL 2019; IV (1): 79 - 85 \\ p-ISSN. 2503-0671 \\ e-ISSN. 2548-5547}

(measurement) dan penilaian atau penafsiran (evaluation), atau dua kegiatan ini: mengukur (measure) dan menilai (evaluate). Pengukuran terjadi apabila seorang guru dengan soal yang dibuatnya, atau tugas yang diberikannya meminta siswa-siswanya mengerjakan soal itu, kemudian mengoreksinya, dan memberikan skor atas pekerjaan siswa (Soewandi, 2007). Untuk dapat mengukur secara benar, perlu alat ukur yang benar pula. Alat ukur yang benar harus memenuhi syarat: sahih (valid), ajeg (reliabel), dan praktis. Di samping ada alat-alat ukur subjektif (esei), objektif (pilihan ganda, penjodohan, isian singkat, dan benar-salah), dan penampilan (performance), sekarang mulai dikenal adanya alat ukur portofolio.

Paling tidak terdapat tiga sikap yang dapat digunakan dalam penilaian, yaitu rasa percaya, lebih tertarik dan keyakinan bahwa proses pembelajaran akan sukses. Selain itu, pengaruh sikap mental guru akan melahirkan kerangka kerja responsif dalam mengajar. Penilaian portofolio merupakan salah satu jenis penilaian yang digunakan dalam penilaian berbasis kelas dan memiliki makna optimal dalam melihat ketercapaian kompetensi belajar peserta didik (Sudrajat, 2016).

Portofolio sebagai kumpulan pekerjaan peserta didik yang menunjukkan usaha, perkembangan dan kecakapan mereka dalam satu bidang atau lebih (Pantiwati, 2011). Kumpulan ini harus mencakup aktivitas peserta didik dalam seleksi isi, kriteria seleksi, kriteria penilaian dan bukti refleksi diri. Penilaian portofolio merupakan penilaian berkelanjutan yang didasarkan pada kumpulan informasi yang menunjukkan perkembangan kemampuan peserta didik dalam satu periode tertentu. Dalam hal ini, penilaian portofolio pada dasarnya menilai karya-karya mahasiswa secara individu pada satu periode untuk suatu mata pelajaran. Akhir suatu periode hasil karya tersebut dikumpulkan dan dinilai oleh dosen dan mahasiswa sendiri.

Portofolio sebagai suatu proses sosial pedagogis adalah pengalaman belajar yang terpadu dan dialami mahasiswa sebagai suatu kesatuan (collection of learning experience) yang terdapat dalam pikiran peserta didik baik yang berwujud pengetahuan (kognitif), keterampilan (skill), maupun nilai dan sikap (Fajar, 2004). Sebagai sebuah kumpulan hasil pekerjaan mahasiswa, portofolio dapat dijadikan bukti untuk menunjukkan usaha, perkembangan dan kecakapan mereka dalam satu bidang atau lebih, menampilkan karya, prestasi dan kemampuan peserta didik (Rusoni, 2001).

Tujuan umum dari penulisan portofolio oleh mahasiswa ada dua, yaitu memberikan penilaian dan pengajaran kepada mahasiswa (Miller, Linn, \& Gronlund, 2009). Selain itu pelajar juga boleh meningkatkan pembelajaran mereka dengan membuat penilaian terhadap tugas mereka sendiri. Hal-hal yang perlu diperhatikan dan dijadikan pedoman dalam penggunaan penilaian portofolio di perkuliahan (Pantiwati, 2011) antara lain: karya mahasiswa adalah benar-benar karya mahasiswa itu sendiri; saling percaya antara dosen dan mahasiswa; kerahasiaan bersama antara dosen dan mahasiswa; milik bersama (joint ownership) antara mahasiswa dan guru; kepuasan; kesesuaian; penilaian proses dan hasil; penilaian dan pembelajaran.

Terdapat 5 langkah secara umum untuk menyusun portofolio yaitu: (1) mengidentifikasi tujuan dan fokus portofolio, (2) Mengidentifikasi dimensi kemampuan umum yang akan dinilai, (3) Mengidentifikasi entri mahasiswa (produk dan aktivitas) yang akan memberikan informasi tentang penilaian, (4) Evaluasi portofolio dan isi, dan (5) Evaluasi rubrik (Nitko \& Brookhart, 2011). Portofolio dapat berupa artefak (produk nyata karya mahasiswa), artikel, jurnal, dan refleksi yang mewakili apa yang telah dilakukan oleh mahasiswa dalam mata pelajaran.

Portofolio dapat digunakan untuk mengases kinerja mahasiswa selama perkuliahan. Asesmen portofolio dapat dibuat bersama oleh dosen dan mahasiswa. Pertama mahasiswa mengumpulkan semua hasil pekerjaannya selama satu semester. Selanjutnya direview untuk menentukan dasar seleksi 
contoh-contoh pekerjaan mahasiswa yang akan dijadikan asesmen. Portofolio digunakan selain sebagai asesmen, juga dapat dipakai untuk membantu mahasiswa merefleksikan apa yang telah mereka pelajari. Beberapa portofolio mahasiswa yang menjadi penilaian dalam penelitian ini adalah laporan tertulis proyek atau penyelidikan individual, tugas, latihan soal, lembar jawaban UTS dan UAS, makalah dan notulensi, serta catatan kuliah.

Kelebihan Portofolio (Miller, Linn, \& Gronlund, 2009), antara lain:

1. Karena portofolio terdiri dari produk instruksi kelas, portofolio dapat segera terintegrasi dengan instruksi.

2. Portofolio memberikan kesempatan kepada siswa untuk menunjukkan apa yang dapat mereka lakukan.

3. Portofolio dapat mendorong siswa untuk menjadi pembelajar yang reflektif dan meningkatkan kemampuan evaluasi tentang kelebihan dan kekurangan pekerjaan mereka.

4. Portofolio dapat membantu siswa bertanggung jawab untuk menetapkan tujuan dan mengevaluasi kemajuan mereka.

5. Portofolio dapat memberikan keuntungan guru dan siswa untuk berkolaborasi dan merefleksikan kemajuan siswa.

6. Portofolio merupakan cara komunikasi yang efektif dengan orangtua dengan menunjukkan contoh konkret dari pekerjaan siswa dan kemajuan demonstrasi.

7. Portofolio dapat menyediakan mekanisme untuk berpusat pada mahasiswa dan konferensi siswa yang terarah dengan orang tua.

8. Portofolio dapat memberikan contoh konkret kepada orangtua perkembangan mahasiswa dari waktu ke waktu serta keterampilan mereka saat ini.

Sedangkan kelemahan portofolio yaitu siswa akan membutuhkan waktu yang lebih lama untuk menyelesaikan, walaupun sebenarnya dalam prosesnya menjadi keuntungan bagi siswa dan jika portofolio dijadikan sebagai dasar untuk tes sumatif, maka reliabilitasnya akan relatif rendah (Miller, Linn, \& Gronlund, 2009).
Aktivitas belajar dapat bersifat fisik maupun mental dalam kegiatan belajar (Sardiman, 2007). Sejalan dengan pernyataan (Wijaya, 1988) yang mengatakan bahwa keaktifan belajar siswa dapat tercermin dalam aktivitas yang dilakukannya. Dengan demikian model pembelajaran berbasis portofolio dapat meningkatkan kualitas proses pembelajaran berupa keaktifan siswa karena peran serta siswa dalam kegiatan belajar dilakukan secara aktif, maka akan meningkatkan keterlibatan fisik dan mental yang optimal pada diri siswa.

Melalui pembelajaran berbasis portofolio, di samping memperoleh pengalaman fisik terhadap objek dalam pembelajaran, mahasiswa juga memperoleh pengalaman atau terlibat secara mental. Pengalaman fisik yang melibatkan mahasiswa atau mempertemukan mahasiswa dengan objek pembelajaran. Pengalaman langsung dalam arti memperhatikan informasi awal yang telah ada pada diri mahasiswa, dan memberikan kebebasan kepada mahasiswa untuk menyusun (merekonstruksi) sendiri-sendiri informasi yang sudah diperolehnya.

Penilaian berbasis portofolio di sini diartikan sebagai kumpulan fakta / bukti dan dokumen berupa tugas-tugas yang terogarnisir secara sistematis dari mahasiswa dalam proses perkuliahan. Selain itu juga diartikan sebagai koleksi sistematis dari mahasiswa dan dosen untuk menguji aktivitas dan hasil belajar. Penilaian berbasis portofolio merupakan pembelajaran praktek (melakukan) dan mempunyai standar pertanyaan yang kuat yakni mendorong adanya interaksi antar lingkungan terkait seperti interaksi antar mahasiswa dan dosen yang saling melengkapi serta menggambarkan belajar mahasiswa secara mendalam yang pada akhirnya dapat membantu mahasiswa menjadi sadar untuk meningkatkan dirinya sebagai pembaca dan penulis yang baik.

Selain itu,belajar matematika berarti belajar untuk mengerti belajar untuk mendefenisikan dan mengkomunikasikan idea dan gagasan yang ada pada grafik, diagram, gambar, variable dan simbol karena matematika 
menjadikan simbol bagian utama dalam memodelkan permasalahan dan bagain utama yang dipelajari (Novriyanto, Maryuni, \& Amri, 2017). Dalam proses pembelajaran matematika, pemahaman konsep merupakan landasan yang sangat penting untuk berpikir dalam menyelesaikan masalah matematika maupun permasalahan sehari-hari (Sari, 2017).

Berdasarkan uraian di atas, tujuan penelitian ini adalah mendeskripsikan peningkatan aktivitas dan hasil belajar mahasiswa pada mata kuliah Pengantar Dasar Matematika mahasiswa semester 1 STKIP Muhammadiyah Kuningan dengan penilaian berbasis portofolio.

\section{Metode Penelitian}

Penelitian ini termasuk Penelitian Tindakan Kelas (PTK). Populasi penelitian ini adalah seluruh mahasiswa STKIP Muhammadiyah Kuningan semester 1, dan sampel penelitiannya adalah mahasiswa semester 1 Program studi Pendidikan Matematika STKIP Muhammadiyah Kuningan.

Waktu penyelenggaraan siklus I dan II pada semester ganjil tahun ajaran 2017/2018, pada mahasiswa angkatan 2017. Sebelum memulai perkuliahan diadakan kontrak belajar dan pemaparan mengenai perkuliahan yang menggunakan penilaian berbasis portofolio beserta teknik pelaksanaannya.

Prosedur kerja yang digunakan dalam pelaksanaan tindakan ini merupakan suatu siklus yang terdiri dari 4 tahap yaitu: (1) perencanaan (planning), (2) tindakan (acting), (3) observasi (observing), (4) refleksi (reflection).

Pada tahap perencanaan (planning), hal yang dilakukan antara lain menyusun RPS mengenai pelaksanaan perkuliahan Pengantar Dasar Matematika. Peneliti juga membuat handout materi Pengantar Dasar Matematika, alat evaluasi (post-test), dan lembar observasi serta menyiapkan peralatan-peralatan untuk mendokumentasikan kegiatan selama proses perkuliahan berlangsung seperti LCD, laptop dan kamera.
Pada tahap tindakan (acting), kegiatan perkuliahan dilaksanakan dengan metode perkuliahan biasa. (1) Dosen melaksanakan tindakan sesuai dengan rencana pelaksanaan perkuliahan yang telah dibuat. (2) Peneliti sekaligus pengamat selama proses perkuliahan berlangsung. (3) Mahasiswa membaca dan mempelajari materi kuliah yang ditugaskan. (4) Mahasiswa diberikan kuis/soal untuk dikerjakan secara kelompok. (5) Dosen dan mahasiswa bersama-sama membahas kuis/soal dan melakukan tanya jawab.

Pada tahap observasi (observing), dosen mengamati terhadap pelaksanaan tindakan meliputi segala aktivitas yang terjadi di kelas. Diantaranya mengamati tanggung jawab perorangan, komunikasi antar mahasiswa, interaksi tatap muka, ajuan pertanyaan dari mahasiswa dan menjawab pertanyaan dari dosen.

Pada tahap refleksi (reflection) dilakukan evaluasi tentang hasil tindakan. Hasil evaluasi yang dilakukan dapat dilihat aktivitas belajar mahasiswa yang belum terpenuhi kemudian dilakukan perbaikan pada kelemahankelemahan yang terdapat dalam perencanaan dan pelaksanaan tindakan siklus sebelumnya.

\section{Hasil dan Pembahasan}

Penelitian ini dilaksanakan pada semester ganjil tahun ajaran 2017/2018, dalam 2 siklus tindakan, siklus I dilaksanakan sebelum UTS dan siklus II dilaksanakan setelah UTS. Data yang diambil dari hasil penelitian ini adalah rata-rata keaktifan mahasiswa selama berdiskusi dan hasil belajar mahasiswa yang diambil dari setiap siklus. Tingkat aktivitas belajar mahasiswa dalam mengikuti perkuliahan dapat dilihat pada tabel 1 di bawah ini.

Tabel 1.

Jadwal pelaksanaan kegiatan pembelajaran

\begin{tabular}{clrr}
\multirow{2}{*}{ No } & \multirow{2}{*}{ Deskriptor } & \multicolumn{2}{c}{ Siklus } \\
\cline { 3 - 4 } & & I & \multicolumn{1}{c}{ II } \\
\hline 1 & Tanggung jawab perorangan & 70,56 & 79,44 \\
\hline 2 & Komunikasi antar mahasiswa & 62,94 & 86,44 \\
\hline 3 & Interaksi tatap muka & 85,69 & 89,13 \\
\hline 4 & Ajuan pertanyaan & 71,69 & 80,5 \\
\hline 5 & Menjawab pertanyaan dosen & 70,93 & 90 \\
\hline Aktivitas klasikal & $\mathbf{7 2 , 3 6}$ & $\mathbf{8 5 , 1}$
\end{tabular}


Berdasarkan hasil pengamatan pada tabel 1 terlihat bahwa aktivitas belajar mahasiswa dengan penilaian berbasis portofolio dari siklus I ke siklus II mengalami peningkatan. Rata-rata nilai tanggung jawab perorangan mengalami peningkatan sebesar 8,88 dari ke siklus II atau sebesar $12,58 \%$. Rata-rata nilai komunikasi antar mahasiswa mengalami peningkatan sebesar 23,5 dari ke siklus II atau sebesar 37,34\%. Rata-rata nilai interaksi tatap muka mengalami peningkatan sebesar 3,44 dari ke siklus II atau sebesar 4\%. Rata-rata nilai ajuan pertanyaan mengalami peningkatan sebesar 8,81 dari ke siklus II atau sebesar $12,29 \%$. Rata-rata nilai menjawab pertanyaan dari dosen mengalami peningkatan sebesar 19,08 dari ke siklus II atau sebesar $26,89 \%$. Sehingga rata-rata nilai aktivitas belajar mahasiswa secara klasikal mengalami peningkatan sebesar 12,74 dari ke siklus II atau sebesar $17,61 \%$. Secara grafik, peningkatan aktivitas belajar mahasiswa digambarkan sebagai berikut.

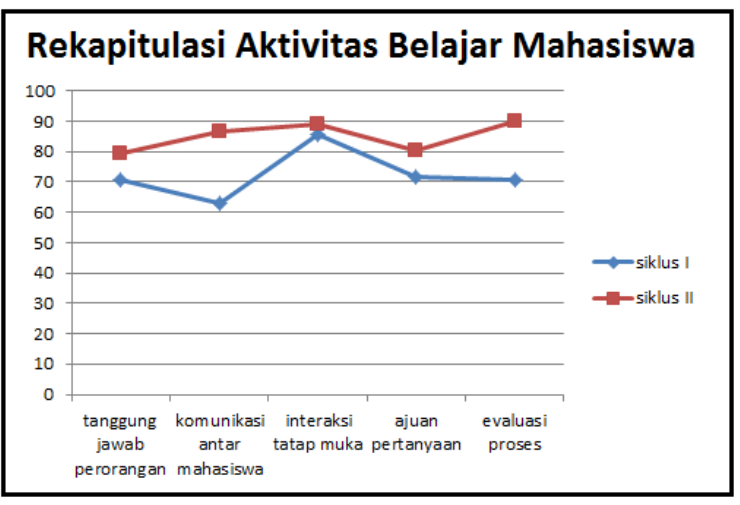

Gambar 1. Grafik peningkatan rata-rata aktivitas belajar mahasiswa

Aktivitas belajar mahasiswa pada siklus I ke siklus II mengalami peningkatan jika dilihat dari beberapa aspek yang diamati. Pada siklus II mahasiswa sudah terbiasa dengan pembelajaran berbasis penilaian portofolio, sehingga mahasiswa termotivasi untuk lebih meningkatkan aktivitas belajarnya selama perkuliahan. Persentase aktivitas belajar klasikal meningkat 12,74 atau sebesar $17,61 \%$. Peningkatan aktivitas belajar mahasiswa teramati terutama dalam aspek komunikasi antar mahasiswa saat berdiskusi dan menjawab pertanyaan dari dosen.
Mahasiswa lebih aktif berkomunikasi dengan temannya saat berdiskusi dan lebih cermat dalam menjawab pertanyaan dari dosen. Sedangkan pada aspek lain yang teramati juga mengalami peningkatan meskipun tidak signifikan.

Portofolio mahasiswa yang menjadi penilaian dalam penelitian ini adalah catatan kuliah, tugas mahasiswa, latihan soal, makalah kelompok, dan presentasi di depan kelas. Hasil penilaian portofolio mahasiswa dapat dilihat dalam tabel 2 berikut ini.

Tabel 2.

Rekapitulasi penilaian portofolio mahasiswa

\begin{tabular}{clcc}
\multirow{2}{*}{ No } & \multirow{2}{*}{ Deskriptor } & \multicolumn{2}{c}{ Siklus } \\
\cline { 3 - 4 } & & I & II \\
\hline 1 & Catatan kuliah & 74 & 88,31 \\
\hline 2 & Tugas & 83,2 & 92,88 \\
\hline 3 & Latihan soal & 78,25 & 85 \\
\hline 4 & Makalah kelompok & 78,56 & 80 \\
\hline 5 & Presentasi & 75 & 85 \\
\hline Penilaian portofolio & $\mathbf{7 7 , 8}$ & $\mathbf{8 6 , 3 8}$
\end{tabular}

Berdasarkan hasil pengamatan pada tabel 2 terlihat bahwa penilaian portofolio mengalami peningkatan dari siklus I ke siklus II. Rata-rata nilai catatan kuliah mengalami peningkatan sebesar 14,31 dari ke siklus II atau sebesar $19,34 \%$. Rata-rata nilai tugas mengalami peningkatan sebesar 9,68 dari ke siklus II atau sebesar 11,63\%. Rata-rata latihan soal mengalami peningkatan sebesar 6,75 dari ke siklus II atau sebesar 8,63\%. Rata-rata nilai makalah kelompok mengalami peningkatan sebesar 10 dari ke siklus II atau sebesar 13,33\%. Rata-rata nilai portofolio mahasiswa mengalami peningkatan sebesar 8,44 dari ke siklus II atau sebesar $10,84 \%$.

Penilaian portofolio mahasiswa pada siklus I ke siklus II juga mengalami peningkatan jika dilihat dari beberapa deskriptor yang diamati. Pada siklus II mahasiswa sudah terbiasa dengan pembelajaran berbasis penilaian portofolio, sehingga mahasiswa termotivasi untuk lebih meningkatkan portofolionya. Persentase penilaian portofolio meningkat 8,44 atau sebesar $10,84 \%$. Peningkatan penilaian portofolio mahasiswa teramati dalam aspek catatan kuliah dan tugas mahasiswa. Mahasiswa 
JURNAL GANTANG. APRIL 2019; IV (1): 79 - 85

p-ISSN. 2503-0671

e-ISSN. 2548-5547

sudah lebih aktif mencatat hal-hal penting selama perkuliahan secara mandiri dan mereka juga lebih rajin dalam mengerjakan tugasyang diberikan dosen. Sedangkan pada aspek lain yang teramati juga mengalami peningkatan meskipun tidak signifikan.

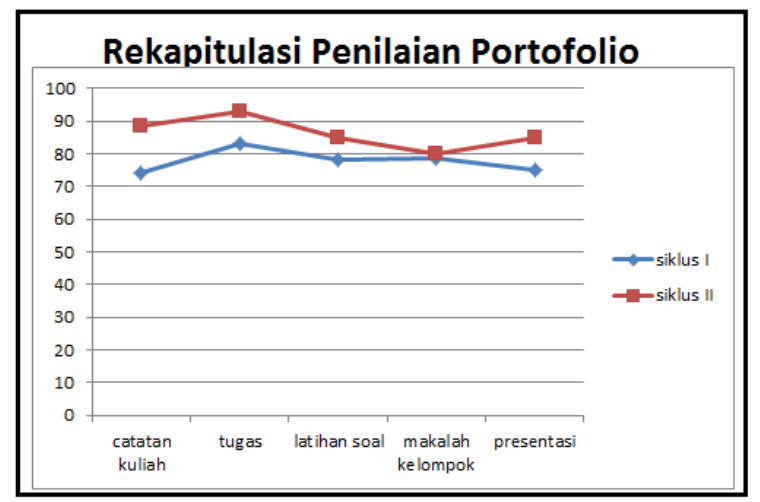

Gambar 2. Grafik peningkatan penilaian portofolio

Hasil belajar mahasiswa dapat dilihat dari nilai Ujian Tengah Semester untuk post test siklus I dan nilai Ujian Akhir Semester untuk post test siklus II. Hasil belajar mahasiswa dapat dilihat pada tabel 3 di bawah ini.

Tabel 3.

Rekapitulasi hasil belajar mahasiswa

\begin{tabular}{cccc} 
Kategori Nilai & Pretest & Siklus I & Siklus II \\
\hline Nilai $<75$ & $100 \%$ & $50 \%$ & $0 \%$ \\
\hline Nilai $\geq 75$ & $0 \%$ & $50 \%$ & $100 \%$ \\
\hline Rata-rata & 43 & 68,4 & 90
\end{tabular}

Berdasarkan hasil pengamatan pada tabel 3 terlihat bahwa proses pembelajaran dengan penilaian berbasis portofolio juga dapat meningkatkan nilai hasil belajar mahasiswa. Terjadi peningkatan rata-rata nilai mahasiswa dari pretest ke post test siklus I yaitu 25,4 atau sebesar $59,07 \%$ dan terjadi peningkatan nilai pula dari post test siklus I ke siklus II sebesar 21,6 atau sebesar $31,58 \%$. Adanya peningkatan hasil belajar mahasiswa ini dapat menggambarkan bahwa penilaian berbasis portofolio ini dapat meningkatkan hasil belajar mahasiswa, karena adanya peningkatan aktivitas belajar mahasiswa secara klasikal.

Hasil penelitian ini menunjukkan bahwa pembelajaran menggunakan penilaian berbasis portofolio dapat mencapai hasil pembelajaran yang bermutu, karena mahasiswa menjadi lebih aktif belajar selama perkuliahan dan akhirnya meningkatkan nilai hasil belajar mereka. Nilai mahasiswa untuk mata kuliah Pengantar Dasar Matematika tidak hanya dilihat dari nilai Ujian Akhir Semester tetapi dilihat dari keseluruhan nilai portofolio yang telah mereka buat selama satu semester. Mahasiswa yang memperoleh nilai A sebanyak $80 \%$ dan sisanya mendapat nilai A-. Hasil ini sangat menggembirakan karena mayoritas mahasiswa memperoleh Indeks Prestasi yang memuaskan.

Hal ini sejalan dengan penelitian Dede Cahyati Sahrir (2016) yang menyatakan bahwa implementasi model pembelajaran berbasis portofolio dapat meningkatkan kualitas proses dan hasil belajar biologi mahasiswa di kelas VI IPA B, program studi PGSD STKIP Muhammadiyah Kuningan.

\section{Kesimpulan}

Simpulan yang diperoleh setelah penelitian ini adalah bahwa pembelajaran dengan penilaian berbasis portofolio dapat meningkatkan aktivitas belajar mahasiswa dan meningkatkan hasil belajar mahasiswa pada mata kuliah Pengantar Dasar Matematika di program studi Pendidikan Matematika STKIP Muhammadiyah Kuningan.

\section{Referensi}

Fajar. (2004). Portofolio dalam pembelajaran. Bandung: Remaja Rosdakarya.

Miller, M. D., Linn, R. L., \& Gronlund, N. E. (2009). Measurement and assessment in teaching. Upper Saddle River, N.J.: Pearson.

Nitko, A. J., \& Brookhart, S. M. (2011). Educational assesment of students. Upper Saddle River, N.J.: Pearson.

Novriyanto, A., Maryuni, N., \& Amri, M. A. (2017). Komunikasi matematis siswa: pengaruh pendekatan matematika realistik. Jurnal Gantang, II(1), 113-123. 
Pantiwati, Y. (2011). Retrieved from http://educloud.fkip.unila.ac.id/index. php?dir=Ilmu\%20Pendidikan/Pendidi kan\%20Guru\%20Sekolah\%20Dasar/ Assesment $\% 20$ Pembelajaran $/ \&$ file $=\mathrm{a}$ ssessmen_pembelajaran_5.pdf.

Rusoni, E. (2001). Retrieved from http://www.pdk.go.id/publikasi/Bulet in/Pppg_Tertulis/08_2001/Portofolio _\&_Paradigma_Baru.html.

Sardiman. (2007). Interaksi dan motivasi belajar mengajar. Jakarta: Rajawali Pres.

Sari, P. (2017). Pemahaman konsep matematika siswa pada materi besar sudut melalui pendekatan PMRI. Jurnal Gantang, II(1), 41-50.

Soewandi, A. S. (2007, Juli). Penilaian pembelajaran dengan portofolio. Jurnal Gatra, XXIII(33), 197-209.

Sudrajat, D. (2016). Portofolio: Sebuah model penilaian dalam kurikulum berbasis kompetensi. Jurnal Intelegensia, 2(1).

Wijaya, C. (1988). Upaya pembaharuan dalam pendidikan dan pengajaran. Bandung: Remaja Karya. 